\title{
Genetic profile of two isolates of Trypanosoma evansi from southern Brazil with different parasitaemias
}

\author{
Daniel Pereira Duarte ${ }^{1}$ \\ Kaio César Simiano Tavares ${ }^{1}$ \\ Cícera Regina Lazzarotto ${ }^{1}$ \\ Larissa Kaori Oide Komati ${ }^{1}$ \\ Éden Ramalho de Araújo Ferreira ${ }^{2}$ \\ Diana Bahia ${ }^{2}$ \\ Luiz Claudio Miletti ${ }^{1 *}$ \\ ${ }^{1}$ Universidade do estado de Santa Catarina, Centro de Ciências Agroveterinárias \\ Laboratório de Bioquímica de Hemoparasitas e Vetores, CEP 88520-000, Lages - SC, Brazil \\ ${ }^{2}$ Universidade Federal de São Paulo, Departamento de Microbiologia, Imunologia e Parasitologia \\ São Paulo - SP, Brazil \\ *Corresponding author \\ 1cmilett@yahoo.com.br
}

Submetido em 07/08/2013

Aceito para publicação em 30/04/2014

\section{Resumo}

Perfil genético de dois isolados de Trypanosoma evansi do Sul do Brasil com diferentes parasitemias. Trypanosoma evansi é o mais difundido dos tripanossomas patogênicos, devido à sua capacidade de ser transmitido mecanicamente por moscas hematófagas. Alguns estudos têm demonstrado que T. evansi possui uma homologia genética entre populações de todo o mundo, mas não descreveram as relações entre os padrões de infecção no hospedeiro. Neste estudo, foram utilizadas técnicas moleculares para determinar as variabilidades genéticas de dois isolados de T. evansi do Sul do Brasil que mostraram diferentes padrões de infecção em modelo murino. Os marcadores de variabilidade genética foram amplificados utilizando as técnicas descritas, bem como a presença de DNA do cinetoplasto também foi verificado. Foi encontrado um perfil genético muito próximo entre os isolados de $T$. evansi utilizando random amplified polymorphic DNA (RAPD) e marcadores inter-simple sequence repeats (ISSR). Os iniciadores derivados da sequência de maxicírculos de Trypanosoma brucei que codificam a subunidade 5 da NADH desidrogenase (nad5) foram usados para demonstrar a ausência de maxicírculos, enquanto imunofluorescência foi usada para verificar a ausência de DNA do cinetoplasto. Todos os métodos demonstram a ausência de kDNA, como ocorre nos isolados americanos de T. evansi. As diferenças notadas nos padrões fenótipicos dos animais que foram observadas durante a infecção não estão, provavelmente, relacionados com as alterações moleculares, mas à adaptação a diferentes hospedeiros, como descrito para outros tripanosomatídeos.

Palavras-chave: Cinetoplasto; RAPD; Trypanosoma evansi; Variabilidade genética 


\section{Abstract}

Trypanosoma evansi is the most widespread pathogenic trypanosome, due to its ability to be mechanically transmitted by hematophagous flies. Some studies have shown that T. evansi has a high genetic homology among populations around the world, but they have not described the relationships among infection patterns in the host. In this study, we used molecular techniques to determine the genetic variability of two isolates of T. evansi from southern Brazil showing different infection patterns in a murine model. Genetic variability markers were amplified using the techniques described, as well as the presence of DNA from kinetoplast was also checked. We found a very close genetic profile between the isolates of $T$. evansi using random amplified polymorphic DNA (RAPD) and markers inter-simple sequence repeats (ISSR). Primers derived from the sequence of Trypanosoma brucei maxicircle encoding the subunit 5 of NADH dehydrogenase (nad5) were used to demonstrate the absence of maxicircles, while immunofluorescence was used to check the lack of DNA from kinetoplast. All methods reveal the absence of kDNA, as occurring in American isolates of T. evansi. Perhaps, differences noticed in the phenotypic patterns of animals that were observed during infection are not associated with the molecular changes, but with the adaptation to different hosts, as described for other trypanosomatids.

Key words: Genetic variability; Kinetoplast; RAPD; Trypanosoma evansi

\section{Introduction}

Trypanosoma evansi is the most widespread pathogenic trypanosome, causing significant morbidity and mortality in breeding and wild animals around the world. The first human case of trypanosomosis caused by $T$. evansi was recently reported in India (JOSHI et al., 2005). This disease is commonly known as "surra" or "mal de cadeiras" and it results in low productivity in animal breeding, which commonly occurs in endemic areas (SEIDL et al., 2001). Trypanosoma evansi infection has been included into the list of notifiable diseases by the World Organization for Animal Health (OIE). Transmission is mechanical and it occurs mainly through fly bites (BRUN et al., 1998).

Recently, a study demonstrated that $T$. evansi is phylogenetically related to T. brucei, but the difference lies on the fact that $T$. evansi lacks some parts of kinetoplastic DNA (LAI et al., 2008), locking the trypanosome at the bloodstream stage, as also shown by Timms et al. (2002). Although genetic exchange of $T$. brucei occurs in the laboratory (JENNI et al., 1986), this process remains unclear, because there are different models suggested for the population structure of trypanosomatids, e.g. clonal population structure and the expansion of few genotypes in a short time frame when genetic exchanges take place (MACLEOD et al., 1999). Thus, the absence of vector phases in $T$. evansi disables genetic recombination (GIBSON; STEVES, 1999; SCHNAUFER et al., 2002) and restricts establishing different genotypes.
The characterization of genotypes has practical implications, such as the establishment of various disease patterns, which make diagnosis more difficult, as well as understanding on parasite spread in areas with low occurrence. Trypanosoma evansi stocks isolated from various world regions (America, Asia, Africa) and animal species (dogs, horses, coatis) have shown that these organisms constitute a genetically homogeneous group. Studies using isoenzymes and analysis of ribosomal internal transcribed DNA (QUEIROZ et al., 2000; LIMA et al., 2008) evidenced this connection. Similar results have been found by using random amplified polymorphic DNA (RAPD) (VENTURA et al., 2002; LUN et al., 2004), amplified fragment length polymorphism (AFLP) (MASIGA et al., 2006), intersimple sequence repeats (ISSR), isoenzymes (QUEIROZ et al., 2000), ribosomes (HUGHES; PIONTKIVSKA, 2003), minisatellite (MACLEOD et al., 1999; NJIRU; CONSTANTINE, 2007; NJIRU et al., 2007), and analysis of expression-site-associated-genes (ESAGs) (WITOLA et al., 2005; MEKATA et al., 2009).

Our laboratory has already noticed different infection patterns in two different isolates of T. evansi in a murine model. In this study, we conducted a multifactorial characterization of these recent isolates to check the relationships between genotypes and the various phenotypes. Additionally, the absence of kDNA was verified. 


\section{Material and Methods}

Two T. evansi stocks confirmed through species specific Polymerase chain reaction (CLAES et al., 2004) were used in this study: one was isolated from a dog (COLPO et al., 2005) and designated as TeD, and the stock designated as $\mathrm{TeH}$ was isolated from a horse, in 2009. Both natural cases occurred in the state of Rio Grande do Sul, southern Brazil. A T. brucei stock was used as control in this study.

Two Wistar rats (Rattus norvegicus) weighing $\sim 220 \mathrm{~g}$ were kept at controlled temperature $\left(23^{\circ} \mathrm{C}\right)$, humidity, and light cycle ( $12 \mathrm{~h} / 12 \mathrm{~h}$ light/dark). All animals received water and food ad libitum. The procedures involving animals were approved by the Animal Welfare Committee of the State University of Santa Catarina (UDESC), under the Protocol 1.42.10, in accordance with the Brazilian legislation and the ethical principles published by the Brazilian College of Animal Experimentation (COBEA).

To obtain the parasites, Wistar rats were infected and their blood was collected at the peak of parasitaemia. After a Percoll ${ }^{\circledR}$ gradient (NDAO et al., 2004), the samples underwent ion exchange chromatography on DEAE-cellulose (LANHAM; GODFREY, 1970). Genomic DNA was obtained using the phenolchloroform method (SAMBROOK; RUSSEL, 2001).
RAPD reactions were performed using six primers from a Ready-to-go ${ }^{\text {TM }}$ RAPD Analysis Beads Kit (GE Healthcare, UK), according to manufacturer's instructions. The similarity coefficient was calculated as described by Nei and Li (1979).

A microsatellite analysis of the marker MORF2-CA was performed using the primers described by Bringaud et al. (1998). In short, the primers were used to amplify a region between RAB1 and ORF2, flanking genes of glucose transporters. Amplicons were sequenced in a Megabace 1000 DNA Analysis System (ACTgene). All high quality DNA sequences (Phred P20) were analyzed using the Phred/Phrap/Consed package (EWING; GREEN, 1998) The identity of sequences was confirmed by the BLAST tool (www.ncbi.nlm.nih.gov/ blast) (ALTSCHUL et al., 1997).

To check the absence of kDNA, specific primers were used to detect the maxicircle sequence of the subunit 5 (nad5) of NADH dehydrogenase (LI et al., 2007) and a fluorescence staining assay with 4,6-diamidino-2phenylindole (DAPI) using T. brucei as control was performed. The sequences of primers and markers used in the present study are shown in Table 1.

\section{Results}

Recently, our laboratory noticed contrasting parasitaemia patterns between two different isolates of

TABLE 1: List of primers used in this study.

\begin{tabular}{|c|c|c|}
\hline & Sequence & Reference \\
\hline RAPD & $\begin{array}{l}\text { P1: 5’(GGTGCGGGAA) } \\
\text { P2: 5`(GTTTCGCTCC) } \\
\text { P3: 5‘(GTAGACCCGT) } \\
\text { P4: 5‘(AAGAGCCCGT) } \\
\text { P5: 5`(AACGCGCAAC) } \\
\text { P6: 5`(CCCGTCAGCA) }\end{array}$ & $\begin{array}{l}\text { Ready-to-go RAPD kit, GE Healthcare } \\
\text { (prod. code 27-9502-01) }\end{array}$ \\
\hline MORF2-CA & $\begin{array}{l}\text { For: 5' (TTTATCTCACATTACTCGGCG) } \\
\text { Rev: 5' (GCGTCGATCATGTCTACCGTAC) }\end{array}$ & BRINGAUD et al. (1998) \\
\hline RoTat 1.2 & $\begin{array}{l}\text { For: 5' (GCGGGGTGTTTAAAGCAATA) } \\
\text { Rev: 5' (ATTAGTGCTGCGTGTGTTCG) }\end{array}$ & CLAES et al. (2004) \\
\hline NADH gene & $\begin{array}{l}\text { For: 5' } \\
\text { (TGGGTTTATATCAGGTTCATTTATG) } \\
\text { Rev: 5' (CCCTAATAATCTCATCCGCAGTACG) }\end{array}$ & LI et al. (2007) \\
\hline
\end{tabular}


T. evansi. TeD was kept by multiple passages through murine models and it reached a strict pre-patent period in 3 to 5 days, the peak of parasitaemia occurs and the animal dies. However, the TeH stock, recently isolated, has shown a long and erratic pre-patent period of more than 21 days without a perceptible peak of parasitaemia, then, a regular peak and animal death. To ensure reliability and identity of samples, both isolates were confirmed as being $T$. evansi using the amplification of RoTat 1.2 antigen, which is a specific variable surface glycoprotein gene (data not shown) and, in both, TeD and TeH, DAPI staining suggests a total absence of kDNA (Figure 1) and the non-amplification of the gene nad5 indicates the absence of maxicircles, which exist in T. brucei.

Then, some techniques were used to check whether different parasitaemia profile of the isolates was due to genetic variability. The RAPD profile (Figure 2 ) showed a high homology (99\%) between $\mathrm{TeD}$ and $\mathrm{TeH}$ isolates. Regarding T. brucei, TeD homology was $99 \%$ and $\mathrm{TeH}$ was $81 \%$. The marker MORF2-CA of TeD isolate has 50 tandem repetitions, while $\mathrm{TeH}$ has 46 repetitions (Figure 3 ), showing identical alleles to some Brazilian isolates already characterized (BITEAU et al., 2000).

FIGURE 1: Fluorescence staining assay showing the absence of kinetoplast. A: T. brucei trypomastigote. B: TeD isolate. C: TeH isolate. Arrow indicates the nucleus and arrowhead indicates the kinetoplast of $T$. brucei.
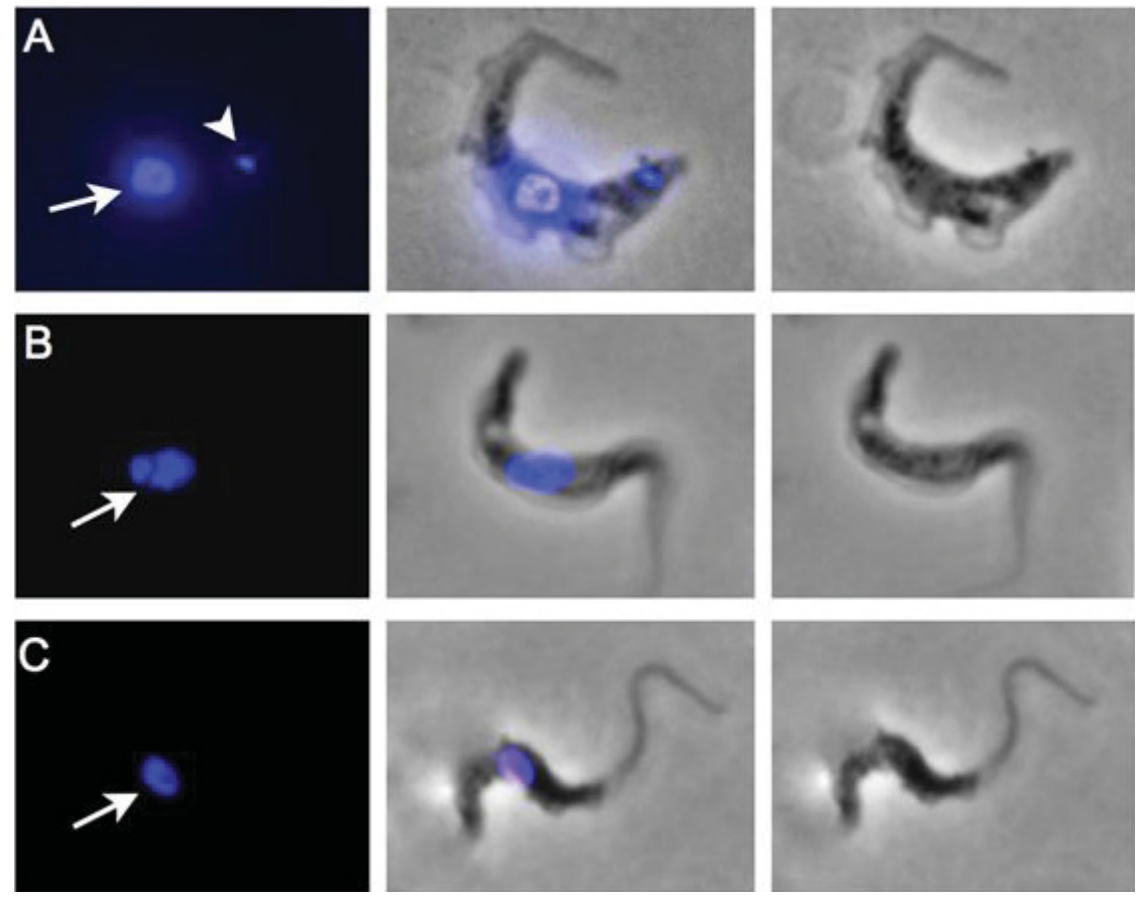

FIGURE 2: RAPD profiles of T. evansi (TeD and TeH) stocks and T. brucei using six primers from RAPD analysis beads kit. Lanes TeD: 1, 4, 7, 10, 13, 16; TeH: 2, 5, 8, 11, 14, 17; T. brucei: 3, 6, 9, 12, 15, 18; M: 100 bp ladder. P1-P6 correspond to RAPD primers.

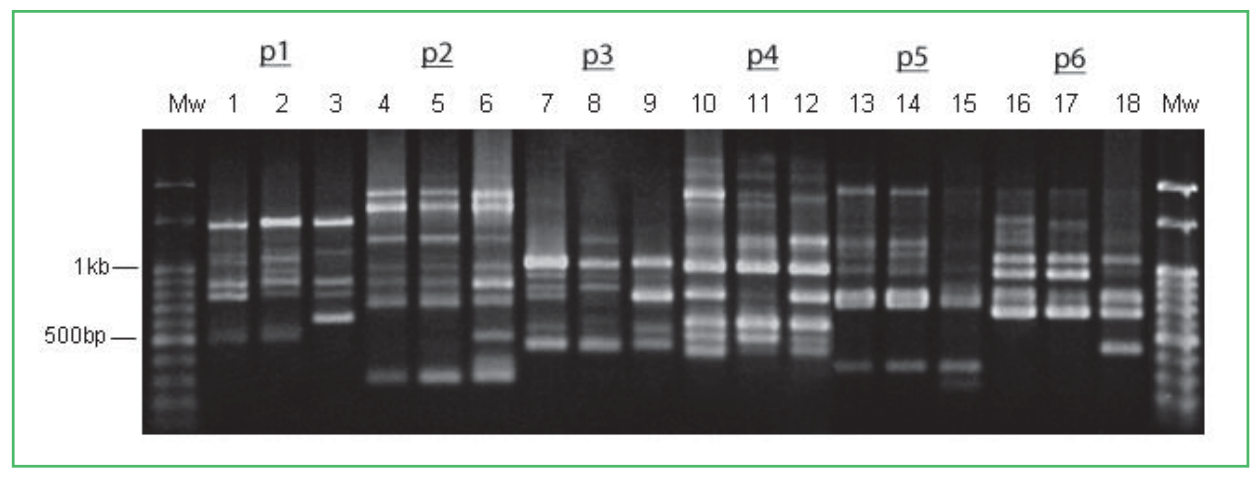


FIGURE 3: Alignments of microsatellite MORF2-CA from T. evansi TeH with 46 repetitions (1) and T. evansi TeD with 50 repetitions (2). Identical nucleotides are represented by asterisks and deletions by dashes.

\begin{tabular}{|c|c|}
\hline TEH & TTTGTGGAAGTATACACACACACACACACACACACACACACACACACACACACAC----ACACACACA----CACACACA 72 \\
\hline \multirow[t]{2}{*}{ TED } & TTTGTGGAAGTATACACACACACACACACACACACACACACACACACACACACACACACACACACACACACACACACACA 80 \\
\hline & 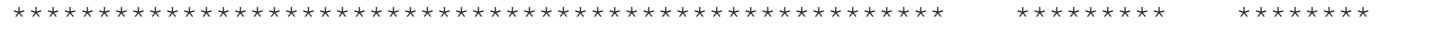 \\
\hline TEH & CACACACACACACACACACACACACACACACACACGCATAGTGCATTGTTTTCCAGTGCTCGACACGCGTGCCCGTTGGT 152 \\
\hline TED & 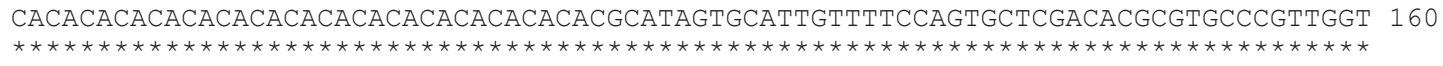 \\
\hline TEH & ACGGTAGACATGATCGACGCAATCGAATTCCCGCGGCCGCCATGGCGGCCGGGAGCATGCGACGTC 218 \\
\hline \multirow[t]{2}{*}{ TED } & ACGGTAGACATGATCGACGCAATCAC-TAGTGATTCGCGCCCTGCAGGTCG--ACCATATG----G 219 \\
\hline & 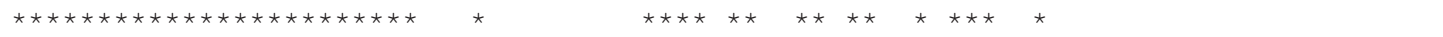 \\
\hline
\end{tabular}

\section{Discussion}

Usually, the infection patterns and clinical features among different $T$. evansi stocks have been observed in few studies of genetic variability (QUEIROZ et al., 2000), since they involve various animal species (BRUN et al., 1998; HERRERA et al., 2004), something which makes it not feasible. We adopted molecular techniques to check the genetic variability between these isolates and whether molecular exchanges are responsible for the differences observed during the infection with $\mathrm{TeD}$ and $\mathrm{TeH}$.

The marker MORF2-CA has been used to characterize and check the phylogeny of different $T$. evansi stocks (NJIRU et al., 2007). As described by Biteau et al. (2000), only small differences on repeated coding sequences at MORF2-CA were observed between the South American isolates. Brazilian stocks already studied had 51 repeats and our isolates have $46(\mathrm{TeH})$ or $50(\mathrm{TeD})$. These are highly sensitive markers that amplify variable regions within microsatellites and minisatellites, since the inter-simple sequence repeats between some genes are frequently modified due to the genome-based nature of eukaryotic cells.

The RAPD technique uses random primers to generate DNA fingerprints and it is useful to identify and genotype various organisms. As observed in other studies using RAPD and restriction fragment length polymorphism RFLP techniques (LUN et al., 2004; LIMA et al., 2008), the high homology between different isolates is a characteristic of $T$. evansi. The clonal population in African trypanosomes (NJIRU; CONSTANTINE, 2007) and the absence of recombination in a vector precludes the genetic variability in T. evansi (LUN; DESSER, 1995; TIMMS et al., 2002). This characteristic also restricts the occurrence of different genotypes in the same host, as found in T. brucei infections (MACLEOD et al., 2000). However, molecular studies have shown a closer genotype in American and Asian stocks when compared to that in African stocks (LUN et al., 2004; LI et al., 2005) and they suggest that $T$. evansi may be classified in sub-populations according to some markers, although with few multi-locus genotypes (NJIRU et al., 2007). The high homology between T. evansi and T. brucei revealed in the RAPD profile suggests that $T$. evansi is closely related to T. brucei and supports the new designation of $T$. brucei evansi, as suggested by Lai et al. (2008).

American stocks of T. evansi have a total absence of a kDNA (VENTURA et al., 2000), while old stocks around the world have partial kDNA composites, usually from minicircles type A. Some isolates from Kenya and Sudan have an aberrant minicircle type B (NJIRU et al., 2006).

The loss of kinetoplast in T. evansi eventually hinders the ability to differentiate biological vectors (no procyclic form) and results in exclusively mechanical transmission through the bloodstream form (BRUN et al., 1998), and it enabled the spread of T. evansi from Africa to other regions of the world (LUN; DESSER, 1995; LUN et al., 2010). Cristodero et al. (2010) found residual mithocondria-specific tRNA editing in akinetoplastid T. evansi, something which suggests that the loss of kDNA was a recent event due to the parasite. 
The genetic variability and its relationship to host pathology have been reported for other trypanosomatids (MACEDO et al., 2002; MORRISON et al., 2009). Despite the complex nature of the phenotypes, Morrison et al. (2009) identified a quantitative trait locus in $T$. brucei that may be related to the pathologic patterns during the infection process. Simultaneously, epigenetic studies of protozoan parasites have revealed that there are correlations between epigenetic mechanisms and virulence factors (LOPEZ-RUBIO et al., 2007; RUDENKO, 2010). In T. brucei, the molecular control of antigenic variation is poorly understood, since it is mainly post-transcriptional and there are epigenetic mechanisms that may control differential and stagespecific expression, unlike other trypanosomatids (LOPEZ-RUBIO et al., 2007).

Other recent studies suggested that the variability in the $T$. evansi transferrin receptor genes could be related to the several different hosts affected by the disease (ISOBE et al., 2003; WITOLA et al., 2005) in which American T. evansi transferrin receptor genes showed more diversity than in Asian T. evansi stocks (MEKATA et al., 2009). The isoenzyme profiles of Brazilian T. evansi stocks showed high biochemical homology while remarkable differences in virulence were observed in these stocks (QUEIROZ et al., 2000). The same characteristic was observed in our isolates when TeD was kept by several passages in rodents and showed increased pathogenicity in the murine model. As described in other recent studies, T. evansi has exceptional genetic homology throughout the world, as also observed in $\mathrm{TeD}$ and $\mathrm{TeH}$ stocks. However, by using this standardized molecular markers, we did not notice significant genetic differences that could be linked to the pathogenic patterns between the parasite and the hosts. Further studies on the molecular characterization of these isolates have been developed.

\section{Acknowledgements}

Both isolates were kindly provided as a gift by Dr. Silvia Gonzalez Monteiro, from the Federal University of Santa Maria (UFSM). Daniel Pereira Duarte held a scholarship from the National Council for Scientific and Technological Development (CNPq). This study was funded by $\mathrm{CNPq}$, the Coordination for Improvement of Higher Education Personnel (CAPES), and the Foundation for Research Support of the State of Sao Paulo (FAPESP).

\section{References}

ALTSCHUL, S. F.; MADDEN, T. L.; SCHÄFFER, A. A.; ZHANG, J.; ZHANG, Z.; MILLER, W.; LIPMAN, D. J. Gapped BLAST and PSI-BLAST: a new generation of protein database search programs. Nucleic Acids Research, Oxford, v. 25, p. 3389-3402, 1997.

BITEAU, N.; BRINGAUD, F.; GIBSON, W.; TRUC, P.; BALTZ, T. Characterization of Trypanozoon isolates using a repeated coding sequence and microsatellite markers. Molecular and Biochemical Parasitology, Amsterdam, v. 105, p. 187-202, 2000.

BRINGAUD, F.; VEDRENNE, C.; CUVILLIER, A.; PARZY, D.; BALTZ, D.; TETAUD, E.; PAYS E.; VENEGAS, J.; MERLIN, G.; BALTZ, T. Conserved organization of genes in trypanosomatids. Molecular and Biochemical Parasitology, Amsterdam, v. 94, p. 249-264, 1998.

BRUN, R.; HECKER, H.; LUN Z. R. Trypanosoma evansi and T. equiperdum: distribution, biology, treatment and phylogenetic relationship a review. Veterinary Parasitology, Amsterdam, v. 79, p. $95-107,1998$.

CLAES, F.; RADWANSKA, M.; URAKAWA, T.; MAJIWA, P.A.O.; GODDEERIS, B.; BÜSCHER, P. Variable Surface Glycoprotein RoTat 1.2 PCR as a specific diagnostic tool for the detection of Trypanosoma evansi infections. Kinetoplastid Biology and Disease, Heidelberg, v. 3, p. 3, 2004.

COLPO, C. B.; MONTEIRO, S. G.; STAINKI, D. R.; COLPO, E. T. B.; HENRIQUES, G. B. Infecção natural por Trypanosoma evansi em cão no Rio Grande do Sul. Ciência Rural, Santa Maria, v. 35 , p. $717-719,2005$

CRISTODERO, M.; SEEBECK, T.; SCHNEIDER, A. Mithocondrial translation is essential in bloodstream forms of Trypanosoma brucei. Molecular Microbiology, New Jersey, v. 78, p. 757-769, 2010.

EWING, B.; GREEN, P. Base-calling of automated sequencer traces using phred. II. Error probabilities. Genome Research, Woodbury, v. 8, p. 186-194, 1998.

GIBSON, W.; STEVES, J. Genetic exchange in the trypanosomatidae. Advances in Parasitology, London, v. 43, p. 1-46, 1999.

HERRERA, H. M.; DÁVILA. A. M. R.; NOREK, A.; ABREU, U. G.; SOUZA, S. S.; D’ANDREA, P. S.; JANSEN, A. M. Enzootiology of Trypanosoma evansi in Pantanal, Brazil. Veterinary Parasitology, Amsterdam, v. 125, p. 263-275, 2004.

HUGHES, A.L.; PIONTKIVSKA, H. Molecular phylogenetics of Trypanosomatidae: contrasting results from 18S rRNA and protein phylogenies. Kinetoplastid Biology and Disease, Heidelberg, v. 2, p.15, 2003.

ISOBE, T.; HOLMES, E.; RUDENKO, G. The transferrin receptor genes of Trypanosoma equiperdum are less diverse in their transferrin binding site than those of the broad-host range Trypanosoma brucei. Journal of Molecular Evolution, Heidelberg, v. 56, p. 377-386, 2003. 
JENNI, L.; MARTI, S.; SCHWEIZER, J.; BETSCHART, B.; LE PAGE, R.W.F.; WELLS, J.M.; TAIT, A.: PAINDAVOINE, P.: PAYS, E.: STEINERT, M. Hybrid formation between African trypanosomes during cyclical transmission. Nature, London, v. 322, p. 173-175, 1986.

JOSHI, P. P.; SHEGOKAR, V. R.; POWAR, R. M.; HERDER, S.: KATTI, R.; SALKAR, H. R.; DANI, V. S.: BHARGAVA, A.: JANNIN, J.: TRUC, P. Human Trypanosomiasis caused by Trypanosoma evansi in India: the first case report. American Journal of Tropical Medicine and Hygiene, Deerfield, v. 73, p. 491-495, 2005.

LAI, D. H.; HASHIMI, H.; LUN, Z. R.; AYALA, F. J.; LUKES, J. Adaptations of Trypanosoma brucei to gradual loss of kinetoplast DNA: Trypanosoma equiperdum and Trypanosoma evansi are petite mutants of T. brucei. Procedings of National Academy of Science USA, Washigton, v. 105, p. 1999-2004, 2008.

LANHAM, S. M.; GODFREY, D. G. Isolation of salivarian Trypanosomes from man and other mammals using DEAEcellulose. Experimental Parasitology, Amsterdam, v. 28, p. 521534, 1970.

LI, F. J.: GASSER, R. B.: LAI, D. H.: CLAES, F.; ZHU, X. Q.; LUN, Z. R. PCR approach for the detection of Trypanosoma brucei and T. equiperdum and their differentiation from $T$. evansi based on maxicircle kinetoplast DNA. Molecular and Cellular Probes, Amsterdam, v. 21, p. 1-7, 2007.

LI, F. J.; GASSER, R. B.; ZHENG, J. Y.; CLAES, F.; ZHU, X. Q.; LUN, Z. R. Application of multiple DNA fingerprints techniques to study the genetic relationships among three members of the subgenus Trypanozoon Protozoa: Trypanosomatidae. Molecular and Cellular Probes, Amsterdam, v. 19, p. 400-407, 2005.

LIMA, A. N. O.; SANTOS, S. S.; HERRERA, H. M.; GAMA, C.; CUPOlillo, E.; JANSEN, A. M.; FERNANDES, O. Trypanosoma evansi: molecular homogeneity as inferred by phenetical analysis of ribosomal internal transcribed spacers DNA of an eclectic parasite. Experimental Parasitology, Amsterdam, v. 118, p. 402-407, 2008.

LOPEZ-RUBIO, J. J.; RIVIERE, L.; SHERF, A. Shared epigenetics mechanisms control virulence factors in protozoan parasites. Current Opinion in Microbiology, Amsterdam, v. 10, p. 560-568, 2007.

LUN, Z. R.; DESSER, S. S. Is the broad range of host geographical distribution of Trypanosoma evansi attributable to the loss of maxicircle kinetoplast DNA? Parasitology Today, Cambridge, v. 11, p. 131-133, 1995.

LUN, Z. R.; LI, A. X.; CHEN, X. G.; LU, L. X.; ZHU, X. Q. Molecular profiles of Trypanosoma brucei, T. evansi and $T$. equiperdum stocks revealed by the random amplified polymorphic DNA method. Parasitology Research, Heidelberg, v. 92, p. 355340, 2004.

LUN, Z. R.; LAI, D. H.; LI, F. J.; LUKES, J.; AYALA, F. J. Trypanosoma brucei: two steps to spread out from Africa. Trends in Parasitology, Amsterdam, v. 26, p. 557-588, 2010.

MACEDO A. M.; OLIVEIRA, R. P.; PENA, S. D. J. Chagas disease: role of parasite genetic variation in pathogenesis. Expert Review in Molecular Medicine, Cambridge, v. 4, p 1-16, 2002.

MACLEOD, A.; TURNER, C. M.; TAIT, A. A high level of mixed Trypanosoma brucei infections in tsetse flies detected by three hypervariable minisatellites. Molecular and Biochemical Parasitology, Amsterdam, v. 102, p. 237-248, 1999.

MACLEOD, A.; TWEEDIE, A.; WELBURN, S. C.; MAUDLIN, I.; TURNER, M. R.; TAIT, A. minisatellite marker analysis of Trypanosoma brucei: reconciliation of clonal, panmictic, and epidemic population genetic structures. Proceedings of National Academy of Science USA, Washington, v. 97, p. 13442-13447, 2000.

MASIGA, D. K.; NDUNG'U, K.; TWIEEDIE, A.; TAIT, A.; TURNER, C. M. R. Trypanosoma evansi: genetic variability detected using amplified restriction fragment length polymorphism AFLP and random amplified polymorphic DNA (RAPD) analysis of Kenyan isolates. Experimental Parasitology, Amsterdam, v. 114, p. 147-153, 2006.

MEKATA H.; KONNAI, S.; WITOLA, W. H.; INOUE, N.; ONUMA, M.; OHASHI, K. Molecular detection of trypanosomes in cattle in South America and genetic diversity of Trypanosoma evansi based on expression-site-associated gene 6. Infection, Genetics and Evolution, Amsterdam, v. 9, p. 1301-1305, 2009.

MORRISON, L. J.; TAIT, A.; MCLELLAND, S.; SWEENEY, L.; TURNER, M. R.; MACLEOD, A. A major genetic locus in Trypanosoma brucei is a determinant of host pathology. Plos. Neglected Tropical Disease, San Francisco, v. 3, n. 3, 2009.

NDAO, M.; MAGNUS, E.; BUSCHER, P.; GEERTS, S. Trypanosoma vivax: a simplified protocol for in vivo growth, isolation and cryopreservation. Parasitology, Cambridge, v. 11, p. 103-106, 2004.

NEI, M.; LI, W. H. Mathematical model for studying genetic variation in terms of restriction endonucleases. Proceedings of National Academy of Science USA, Washington, v. 76, p. 52695273, 1979.

NJIRU Z. K.; CONSTANTINE, C. C. Population sub-structuring among Trypanosoma evansi stocks. Parasitology Research, Heidelberg, v. 101, p. 1215-1224, 2007.

NJIRU, Z. K.; CONTANTINE, C. C.; GITONGA, P. K.; THOMPSON, R. C. A.; REID, S. A. Genetic variability of Trypanosoma evansi isolates detected by inter-simple sequence repeat anchored-PCR and microsatellite. Veterinary Parasitology, Amsterdam, v. 147, p. 51-60, 2007.

NJIRU, Z. K.; CONTANTINE, C. C.; MASIGA, D. K.; REID, S. A.; THOMPSON, R. C. A.; GIBSON, W. C. Characterization of Trypanosoma evansi type B. Infection, Genetic and Evolution, Amsterdam, v. 6, p. 292-300, 2006.

QUEIROZ, A. O.; CABELLO, P. H.; JANSEN, A. M. Biological and biochemical characterization of isolates of Trypanosoma evansi from Pantanal of Matogrosso - Brazil. Veterinary Parasitology, Amsterdam, v. 92, p. 107-118, 2000.

RUDENKO, G. Epigenetics and transcriptional control in African trypanosomes. Essays in Biochemistry, London, v. 48, p. 201-219, 2010.

SAMBROOK, J.; RUSSELL, D. W. Molecular cloning: a laboratory manual. 3. ed. Cold Spring Harbor: Cold Spring Harbor Laboratory Press, 2001. 2344 p.

SCHNAUFER, A.; DOMINGO, G. J.; STUART, K. Natural and induced dyskinetoplastic Trypanosomatids: how to live without mitochondrial DNA. International Journal for Parasitology, Amsterdam, v. 32, p. 1071-1084, 2002. 
SEIDL, A. F.; MORAES, A. S.; SILVA, R. A. M. S. A. Trypanosoma evansi control and horse mortality in Brazilian Pantanal. Memórias do Instituto Oswaldo Cruz, Rio de Janeiro, v. 96, p. 599-602, 2001.

TIMMS, M. W.; DEURSEN, F. J.; MATTEWS, K. R. Mitochondrial development during life cycle differentiation of African Trypanosomes: evidence for a kinetoplast-dependent differentiation control point. Molecular Biology of the Cell, Bethesda, v. 13, p. 3747-3759, 2002.

VENTURA, R. M.; TAKATA, C. S.; SILVA, R. A.; NUNES, V. L.; TAKEDA, G. F.; TEIXEIRA, M. M. Molecular and morphological studies of Brazilian Trypanosoma evansi stocks: the total absence of kDNA in trypanosomes from both laboratory stocks and naturally infected domestic and wild mammals. Journal of Parasitology, Lawrence, v. 86, p. 1289-1298, 2000.
VENTURA, R. M.; TAKEDA, G. F.; SILVA, R. A.; NUNES, V. L.; BUCK, G. A.; TEIXEIRA, M. M. Genetic relatedness among Trypanosoma evansi stocks by random amplification of polymorphic DNA and evaluation of a synapomorphic DNA fragment for species-specific diagnoses. International Journal for Parasitology, Amsterdam, v. 32, p. 53-63, 2002.

WITOLA, W. H.; SARATAPHAN, N.; INOUE, N.; OHASHI, K.; ONUMA, M. Genetic variability in ESAG6 genes among Trypanosoma evansi isolates and in comparison to other Trypanozoon members. Acta Tropica, Amsterdam, v. 93, p. 63-73, 2005. 